\title{
Management of nature-based goods and services provisioning from the urban common: a pan-European perspective
}

\author{
Abhishek Tiwary¹, Ursa Vilhar², Miglena Zhiyanski ${ }^{3}$, Vladimir Stojanovski ${ }^{4}$, Lucian Dinca ${ }^{5 *}$
}

${ }^{1}$ Institute of Energy and Sustainable Development, De Montfort University, Leicester, UK;

${ }^{2}$ Slovenian Forestry Institute, Večna pot 2, 1000 Ljubljana, Slovenia;

${ }^{3}$ Forest Research Institute - Bulgarian Academy of Sciences, 132 Kliment Ohridski Blv. 1756 Sofia, Bulgaria;

${ }^{4}$ Hans Em - Faculty of Forest Science, Landscape Architecture and Environmental Engineering, "Ss. Cyril and Methodius" University in Skopje, 1000 Skopje, Republic of North Macedonia

${ }^{5}$ National Institute for Research and Development in Forestry "Marin Dracea", 13 Closca Street, Brasov, Romania; dinka.lucian@gmail.com

* Correspondence: dinka.lucian@gmail.com; Tel.: +40-724012688

\begin{abstract}
The role of the urban common (i.e. shared space and resources) in sustainable provisioning of goods and services to city dwellers is discussed in this paper. Focusing on tree-based green infrastructure, the study scope includes three categories of provisioning (woody biomass, food/fibre, and non-timber forest products, i.e. NTFPs), alongside three categories of supporting services (fresh water replenishment, soil nutrient restoration, building preservation). As a first step, prospects of utilizing the urban common as facilitator of nature-based solution to the earmarked provisioning services are evaluated through dedicated literature survey and expert elicitation on perceived impact of environmental change triggers and management interventions (planning and/or governance). This is followed by a structured review of the state of affairs in four European cities (London, Amsterdam, Sofia, Ljubljana), representing different macro-geographical regions with distinct socio-economic drivers in managing these provisioning services. The pan-European expert elicitation exercise noted active management of the urban common as positively impacting on the performance of the majority of provisioning services, while environmental change impacts were found to be overriding and adversely influencing the provisioning of material resources (mainly NTFPs and woody biomass). The four-city case study highlighted some regional peculiarities in connecting the city dwellers to the urban common and identified the need to overcome socio-cultural barriers for enhancing pan-European best practice sharing in the management of goods and services provisioning. This is deemed essential to pave way for an emerging perspective on sustainable utilization of the urban common as an enabler for nature-based solution, making it fit for purpose in meeting the astronomical demands of future urban living.
\end{abstract}

Keywords: Green infrastructure; Nature-based solution; Non-timber forest products; Provisioning services; Urban common 


\section{Introduction}

The urban common is a shared space which can promote socio-ecological resilience within heavily

2 urbanized systems by reclaiming the city for the public good, and therefore can offer the residents a sustainable participatory alternative to exclusive urban development (Colding and Barthel, 2013; Schauppenlehner-Kloyber and Penker, 2016). Such innovative eco-urbanism utilizing local resources for provisioning of goods and services is becoming increasingly important to support a predominantly urban population, expected to represent around 60\% globally by 2030 (WHO, 2016). To this end, deeper understanding of the attributes and barriers to their systematic integration in urban planning to maximum effect has become imperative (Kohsaka et al., 2013). Typically, cities in Europe and North America are creating a new rural urbanism, adopting innovative forms of urban agriculture that synthesize agriculture, nature conservation, infrastructure and communities. For example, the Agrocité project in the suburbs of Paris, has adopted a bottom-up strategy for resilient urban regeneration with over 400 citizens co-managing 5000 square meters of land, producing food, energy and housing, while actively reducing waste and water usage (Armstrong and Lopes, 2016). Other initiatives, such as the use of peri-urban lakes in Bengaluru, India (Mundoli et al., 2015) and the fresh water resources in the Murray-Darling Basin, Australia (Liu et al., 2013), serve recent examples of the use of common resources to meet the growing demands of urbanization. The EU Research and Innovation policy has emphasized on 'innovating with nature' through its agenda on Nature-Based Solutions and Re-Naturing Cities (EC, 2015). A number of European studies have focused efforts on mapping multiple ecosystem services to understand either the spatial distribution of their benefits and costs (Grêt-Regamey et al., 2013), or the gap between supply and demand of urban ecosystem services through user preference assessments (Casado-Arzuaga et al., 2013). This has allowed for a more need-based consideration of the inherent spatial synergies and trade-offs while managing ecosystem services.

Trees are typical multi-functional entities of the urban common, yet their role in provisioning ecosystem services is pretty ad hoc (Tiwary et al., 2016). More strategic planning of the urban common, accounting for its biocultural diversity and the interactions people have with its different components, has been identified a way forward in enhancing its local service potential (Buizer et al., 2016). Responding to this challenge, several cities in the United Kingdom have seen revival in restoration and harvest of orchards in the urban common for fruit and nut trees (The Orchard Project, 2016). The GREEN SURGE project has recently assessed the ecosystem service provisioning and the demand for urban green space across Europe at two scales - Urban Learning Lab and European Atlas Cities (Cvejić et al., 2015). The European BiodivERsA project - Urban Biodiversity and Ecosystem Services (URBES) - focused on European city regions with distinct geographical characteristics (Berlin, Rotterdam, Salzburg, Stockholm, Helsinki, Lódz and Barcelona) to test a range of indicators for a set of earmarked ecosystem goods and services, including local climate regulation, air cooling potential and recreation along an urban-rural gradient (Larondelle, and Haase, 2013). Greater emphasis is being laid by municipalities to adopt a 'natural capital approach' towards promoting ecosystem services from their multifunctional urban green infrastructures (UGIs) (NCC, 2015). Furthermore, the role of perennial food provisioning from the urban common has been assessed differently from conventional urban agriculture as part of the newly coined concept of 'urban food forestry', based on of their cold hardiness, drought tolerance and edibility (Clark and Nicholas, 2013). 
There is a need for more informed evaluation of the role of urban common in provision of goods derived from plants and fungi to support wild foods, medicines, livelihoods, and other sociocultural values and needs (Poe et al., 2013). While guidance has been developed on mapping urban ecosystems and their services at the continental, member state and local level in Europe (Maes et al., 2013), along with an indicator framework to assess their level of performance using country-specific database of provisioning services from the urban common (mainly covering food, fuel, fibre and water) (Maes et al., 2016), there is still a lack of cross-geographical spatial information at the European level.

Our paper presents a comprehensive understanding of the management potentials of tree-based goods and services provisioning from the urban common. The first part of the study is conducted with two-fold objectives: one, to develop a baseline understanding of the role of the urban common in sustainable goods and services provisioning across different socio-geographical settings; two, to assess the potential role of management initiatives in developing nature-based provisioning solution for an increasingly urban-centric world. This is followed by a four-city case study, which captures the diverse geo-political and socio-economic set up across Europe, offering a basis for further implementation of available resources to their fullest potential, so that cities can become more independent and thereby relieve pressure from their surroundings. It helps in identifying the missing provisional goods and services per case, which can be further useful for urban policy makers and planners in creating future EU-wide eco-urbanism strategies, as well as national policies and urban planning. Taking a pan-European perspective it highlights the regional initiatives as manifestation of socio-cultural practices (i.e. bottom-up initiative) and/or government policy instruments (i.e. top-down initiative) and calls for a balanced compromise between the two initiatives through wider knowledge sharing across Europe. The study advances a framework for better identification of a variety of nature-base solutions systems, like urban green infrastructure (UGI), which could contribute to closing as many resource loops as possible within the city limits.

\section{Materials and Methods}

\subsection{Meta-data assessment}

This assessment mainly concerns provisioning services of the urban common, primarily focusing on its tree-based green infrastructure component. The urban common scoped in this study mainly include urban parks and woodlands, lines of street trees and patches of tree stands in public spaces. Following the convention, the spatial scope of the assessment covers urban, and peri urban (mainly commercial/industrial, construction/dumping sites) and transport corridors (Maes et al., 2013). The trees included predominantly comprise of synanthropic species, which are associated with urban habitats as either isolated trees (single/clusters or woods) or parks/green areas (e.g. gardens), the latter usually mixtures of ground vegetation and trees. We adopted the systematic review methodology recommended for environmental research, which includes construction of an a priori protocol, comprehensive searching of literature and the application of predefined criteria to identify relevant articles, followed by critical appraisal of their methodological quality and findings (Bowler et al., 2010). A spreadsheet-style inventory was developed iteratively through a series of interdisciplinary elicitations involving a pan-European team of experts from the GreenInUrbs COST1204 Action consortium, identifying a list of parameters for the different goods and services categories included in this assessment. Selection and definition of parameters used in construction of the a priori search protocol were 
urban ecosystems in the mapping and assessments of ecosystems and their services (MAES) reports (Maes et al, 2013; Maes et al., 2016). The literature search focused on published peer-reviewed journals, books, web-based practice literature and reports from the European Environmental Agency (EEA); UN Millennium Ecosystem Assessment; The Economics of Ecosystems and Biodiversity (TEEB) have been included along with some additional frameworks like MAES; International Classification of Ecosystem Services (CICES); System of Environmental-Economic Accounting (SEEA). Initial keyword searches were conducted primarily for the electronic resources (GoogleScholar and Scopus ${ }^{\circledR}$ ), confining the metadata search to European studies to fulfill the study objective. This involved content analysis using relevant keywords (e.g. 'ecosystem goods', 'provisioning services', 'shared space', 'urban common', 'urban forestry', 'urban trees', 'green infrastructure', etc.). Only those studies which investigated at least one of the three broad categories of provisioning of ecosystem goods and other services for human consumption (woody biomass; food/fibre; non-timber forest products (NTFPs)), as identified in the Common International Classification of Ecosystem Services (CICES, 2014), have been included. In addition to the CICES classification, some supporting services of the urban common are also considered, such as soil nutrient restoration/preservation; water restoration/replenishment; building preservation (MEA, 2005) (Figure 1). Additional local studies, not published either in the popular journals or on the web, were accessed locally by the author-team for their respective region within the scoped goods and services. In some cases, this included personal communications with experts and different stakeholders.

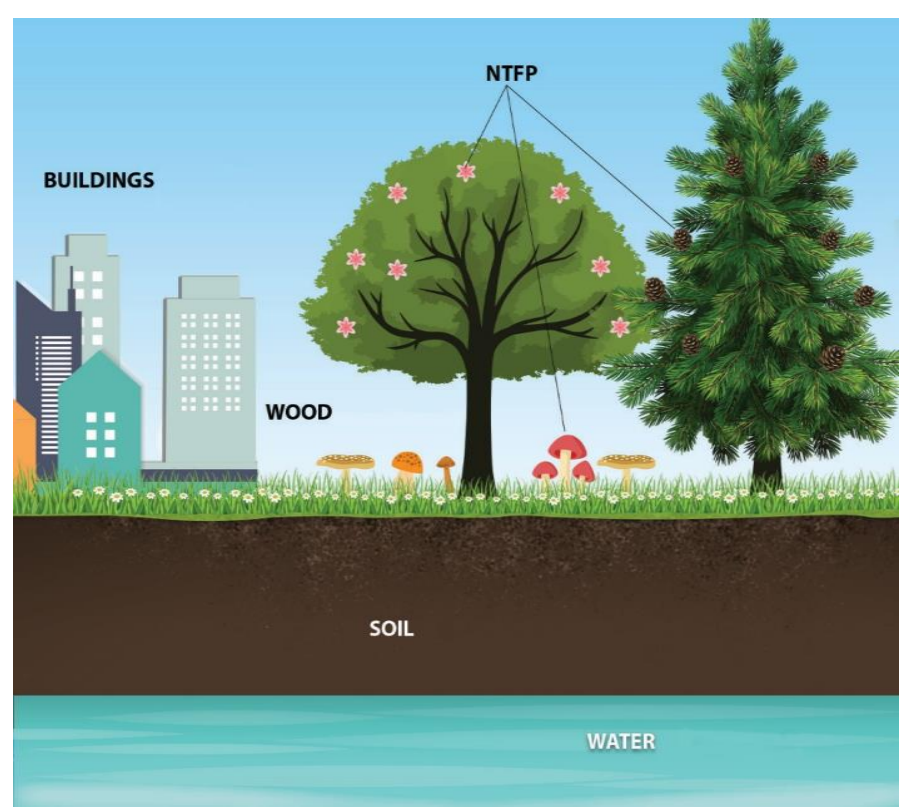

Figure 1. Info graphic showing typical tree-based good and services provision potential from the urban commons, including wood, soil, water and non-timber forest products (NTFP), alongside building preservation in inner cities.

The literature data was consolidated to evaluate available evidence on the status quo of the intensities of the different goods and services acquired from the urban common. Alongside, potential trends for the dependence of their health on environmental change, as well as the scope for further enhancement and/or limitations from urban planning, management and governance, were evaluated (Table 2). The latter involved synthesis of multidisciplinary knowledge from various experts involved on the EU-FP7 Cost GreenInUrb project, ensuring pan-European inputs to the evaluation. The elicitation panel comprised of 10 experts, 
comprising of specialist knowledge in urban planning, community forestry, soil science, urban agriculture, catchment hydrology, contaminated land management, landscape architecture, and infrastructure resilience.

109 The deliberations involved evaluation of the pros and cons of environmental change triggers, practical 110 interventions (planning and/or management) and limitations (governance) to develop a collective score 111 showing the overall trend for each category (increasing: $\uparrow$; decreasing: $\downarrow$; unchanged: $\leftrightarrow$; undetermined: - ), as 112 shown in Table 2. This was based mainly on evaluation of the qualitative information for the categories, 113 interpreted on a 1-10 Likert scale, and were ratified iteratively through rounds of follow up meetings and 114 discussions to develop consensus on the evaluation procedure.

\subsection{Four-city case study}

Following a broader understanding of the typological trends, this step focused on closer scrutiny of the spatial heterogeneity (if any) and the emerging trends of provisioning services from the urban common across different socio-economic regions. For this purpose, four characteristically different European regions (Northern, Eastern, Western and Southern) were identified following the UN regional classification of Europe based on macro geographical (continental) composition, geographical sub-regions, and economic and other groupings (UN, 2013). Correspondingly, capital cities of representative countries in the four selected European regions were chosen as follows: London (North, $51.5074^{\circ} \mathrm{N}, 0.1278^{\circ} \mathrm{W}$ ), Sofia (East, $42.6977^{\circ} \mathrm{N}, 23.3219^{\circ} \mathrm{E}$ ),

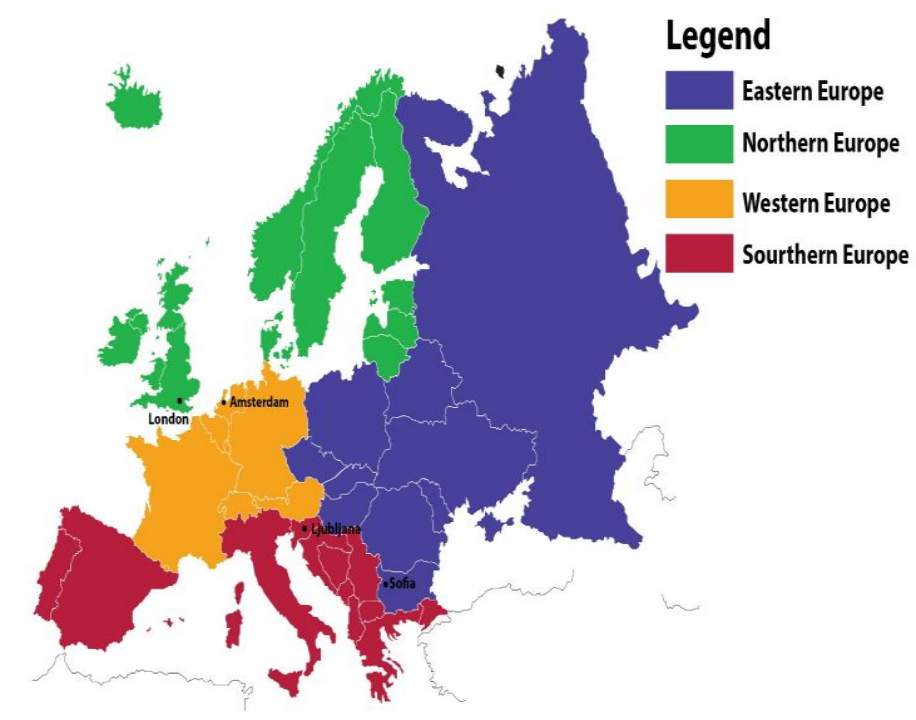

Figure 2. Map depicting the color-coded spatial representativeness of the four case study sites across Europe chosen for this assessment.

London is a megalopolis with over 8.5 million inhabitants; Sofia and Amsterdam are medium-size cities with more than 1 million inhabitants; Ljubljana is a small city with just around 300,000 inhabitants. Concerning the comparison of provisioning services from the urban common, all four cities were relevant due to their regional differences and efforts in intensively researching on issues affecting urban forestry and urban GI within

134 the last few years. Ljubljana in particular was nominated for Green Capital of Europe Award in 2016. We conducted structured review of the content already acquired in Section 2.1, but on this occasion focusing more on the city-specific literature and web materials. This was underpinned by the quest for identifying the 
knowledge gaps in the current practice of goods and services delivery from the urban common, in order to

138 facilitate transferable learning across Europe. A template was developed through brainstorming by the authors

139 in the first step (Table 3) to document the reviewed sources for the chosen cities. This focused mainly on

140 reviewing the city-specific local plans on green infrastructure management, annual tree audits, reported

141 community-scale initiatives, etc. In some cases, additional information was also acquired through direct liaisons

142 with the respective statistical offices, as well as through direct interviews/personal communications with

143 relevant city planning authorities. Crucial to the aim of our study, this exercise also allowed stocktaking of the

144 regional trends and the distinct priorities (perceived and/or evidenced through literature), highlighting the

145 socio-cultural disparities and the priorities of the city authorities in the four European regions.

\section{3. Results}

\subsection{Meta-data assessment}

Broader typological trends emerging from our pan-European review are summarized in Table 1, which shows relatively higher intensities of reporting of conventional provisioning/supporting services (biomass, soil preservation, water restoration) and rather feeble reporting on utilization of the urban commons for other aspects, such as acquisition of valuable goods (food/fibre, NTFPs), as well as more innovative supporting service (building preservation). For example, we note a lack of sufficiently reported evidence concerning the provisioning of goods from the urban common in the European context, specifically for material resources, where the majority of the available literature originated from outside Europe (e.g. USA, China etc.), hence excluded from the scope of this assessment. This drastic variation in the volume of available literature on the individual categories of the earmarked goods and services indicates the potential role urban commons can play in enhancing the provisioning of goods to cater to the growing urban population through adequate policy instruments.

Table 1. Summary of the systematic review of European literature on provision of earmarked goods and 161

\begin{tabular}{|c|c|c|c|}
\hline Scoped Category & $\begin{array}{c}\text { No. of } \\
\text { studies }^{\text {a }}\end{array}$ & Countries involved & $\begin{array}{c}\begin{array}{c}\text { Example of European } \\
\text { studies }\end{array} \\
\end{array}$ \\
\hline $\begin{array}{l}\text { Biomass (woody } \\
\text { resources) }\end{array}$ & 21 & $\begin{array}{l}\text { Bulgaria, France, Germany, } \\
\text { Greece, Italy, Poland, Romania, } \\
\text { Sweden, UK }\end{array}$ & $\begin{array}{l}\text { Bolea et al., 2015; Carlini et al., 2013; Dimitrov et al., } \\
\text { 2018; Djomo et al., 2015; Ebenhard et al., 2017; } \\
\text { Ferrari et al., 2017; Giannico et al., 201; Grunewald et } \\
\text { al., 2017; Pesola et al., 2017; Seidel et al, } 2015 \text {. }\end{array}$ \\
\hline Food/fibre & 10 & $\begin{array}{l}\text { Italy, Poland, Romania Spain, } \\
\text { Sweden, UK }\end{array}$ & $\begin{array}{l}\text { Chisăliță et al., 2017; Shackleton et al., 2017; } \\
\text { www.theorchardproject.org.uk/ }\end{array}$ \\
\hline $\begin{array}{l}\text { Non-timber forest } \\
\text { products }\end{array}$ & 10 & $\begin{array}{l}\text { Finland, France, Greece, } \\
\text { Romania, Sweden, UK }\end{array}$ & $\begin{array}{l}\text { Konijnendijk, 2008; Enescu et al., 2017; Enescu et } \\
\text { al., } 2018\end{array}$ \\
\hline $\begin{array}{l}\text { Soil (restoration/ } \\
\text { nutrient preservation) }\end{array}$ & 22 & $\begin{array}{l}\text { Italy, Poland, Romania, Serbia, } \\
\text { Spain, UK }\end{array}$ & $\begin{array}{l}\text { Cakmak et al., 2018; Chrzan, 2015; Dinca et al., } \\
\text { 2015; Ferrara et al., 2015; Markkola et al., 2002; ; } \\
\text { Orłowski et al., 2014; Tarvainen et al., 2011; } \\
\text { Țenche- Constantinescu et al., } 2015 \text {. }\end{array}$ \\
\hline $\begin{array}{l}\text { Water (restoration/ } \\
\text { replenishment) }\end{array}$ & 19 & $\begin{array}{l}\text { Czech Republic, Italy, } \\
\text { Romania, Slovenia, Spain }\end{array}$ & $\begin{array}{l}\text { Capotorti et al., 2015; Hernea et al., 2013; Kachova } \\
\text { and Dinca, 2015; Livesley et al., 2016; Sraj et al., } \\
\text { 2008; Vilhar et al., } 2012\end{array}$ \\
\hline $\begin{array}{l}\text { Built space } \\
\text { (preservation/MAES) }\end{array}$ & 13 & $\begin{array}{l}\text { Austria, Belgium, Bulgaria, } \\
\text { Italy, Denmark, Finland, } \\
\text { Netherlands, Sweden, UK }\end{array}$ & $\begin{array}{l}\text { Arnberger and Eder, 2006; Godefroid and Koedam, } \\
\text { 2003; Hansen-Møller and Oustrup, 2004; } \\
\text { Konijnendijk et al., 2007; Nedkov et al., 2017; Perini } \\
\text { et al., 2011; Raji et al., 2015; Sanesi et al., 2011; } \\
\text { Tiwary and Kumar, 2014; Tyrväinen, 2001. }\end{array}$ \\
\hline
\end{tabular}

a including unpublished, regional and local initiatives

Table 2 provides a list of tangible goods and services acquired from the urban common, along with a 
representative urban ecosystem' on the influence of environmental change (urban microenvironment) and anthropogenic impacts (mainly management or the lack of it), based on the deliberations of the elicitation panel

168 (Section 2.1). While the role of active management was shown to positively impact on the performance of the majority of provisioning services, environmental change impacts were found to be adversely influencing the provisioning of NTFPs and woody biomass. Despite the local climate impacting negatively on these provisioning, the 'effective impact' score in the majority of these categories still showed an upward trend,

172 largely due to the improved management practices counterbalancing the environmental change impacts. As 173 with previous systematic review of ecological data, this exercise posed significant challenges, particularly 174 owing to the inconsistencies in the quantity, accessibility and diverse quality of available data (Pullin and Stewart, 2006). However, the overall trends emerging from our review of the published literature on the goods and services offered from the urban common is strongly supportive of their economic benefits to the residential population, thus facilitating the 'green economy'. These trends extend the concepts of environmental psychology and cultural ecology studies, which have demonstrated the positive effects of gardening and being in nature (McLain, 2012). Based on this assessment, we consider future ecosystem service assessments on various temporal and spatial scales in urban ecosystems can provide information on provisioning ecosystem services, quantifying the likelihood of urban land-use, specifically the commons, and its probable impact on ecosystem functions and service supply/demand, and understand the value and flow of benefits to the human populations.

Table 2. List of tree-based goods and other services acquired from the urban commons, including their constituent indicative parameters. Presented alongside are the potential perceived effect of environmental change and management, evaluated on the basis of pan-European expert elicitations [note: increasing: $\uparrow$; decreasing: $\downarrow$; unchanged: $\leftrightarrow$; undetermined: - ].

\begin{tabular}{|c|c|c|c|c|}
\hline $\begin{array}{l}\text { Goods/Service } \\
\text { category }\end{array}$ & Constituent parameters & $\begin{array}{c}\text { Projected } \\
\text { environmental } \\
\text { change impact } \\
\end{array}$ & $\begin{array}{c}\text { Role } \\
\text { of } \\
\text { management } \\
\end{array}$ & $\begin{array}{l}\text { Effective impact } \\
\text { (Environmental + } \\
\text { Management) } \\
\end{array}$ \\
\hline \multirow[t]{3}{*}{$\begin{array}{c}\text { Soil nutrient } \\
\text { restoration/ preservation }\end{array}$} & & $\uparrow$ & $\uparrow$ & $\uparrow$ \\
\hline & Ground vegetation cover & $\uparrow$ & $\uparrow$ & $\uparrow$ \\
\hline & $\begin{array}{l}\text { Root system/ Sap flow } \\
\text { rate }\end{array}$ & - & $\uparrow$ & - \\
\hline \multirow[t]{3}{*}{$\begin{array}{l}\text { Water restoration/ } \\
\text { replenishment }\end{array}$} & & $\uparrow$ & $\uparrow$ & $\uparrow$ \\
\hline & $\begin{array}{c}\text { Leaf traits (shape and } \\
\text { orientation; evergreen vs } \\
\text { deciduous) }\end{array}$ & $\leftrightarrow$ & $\uparrow$ & $\uparrow$ \\
\hline & Canopy area & $\downarrow$ & $\uparrow$ & - \\
\hline \multicolumn{5}{|l|}{ Non-timber forest } \\
\hline \multicolumn{5}{|l|}{ Fungi and Forest floor } \\
\hline & Accessibility & $\downarrow$ & $\uparrow$ & - \\
\hline & Commercial value & $\uparrow$ & $\uparrow$ & $\uparrow$ \\
\hline & Tree count & $\leftrightarrow$ & $\uparrow$ & $\uparrow$ \\
\hline \multirow[t]{4}{*}{ Woody biomass } & & $\downarrow$ & $\uparrow$ & $\uparrow$ \\
\hline & Tree species cultivar & $\downarrow$ & $\downarrow$ & $\downarrow$ \\
\hline & $\begin{array}{l}\text { Tree physiology (height, } \\
\text { width) }\end{array}$ & $\leftrightarrow$ & $\uparrow$ & - \\
\hline & Above ground biomass & $\downarrow$ & $\uparrow$ & - \\
\hline
\end{tabular}




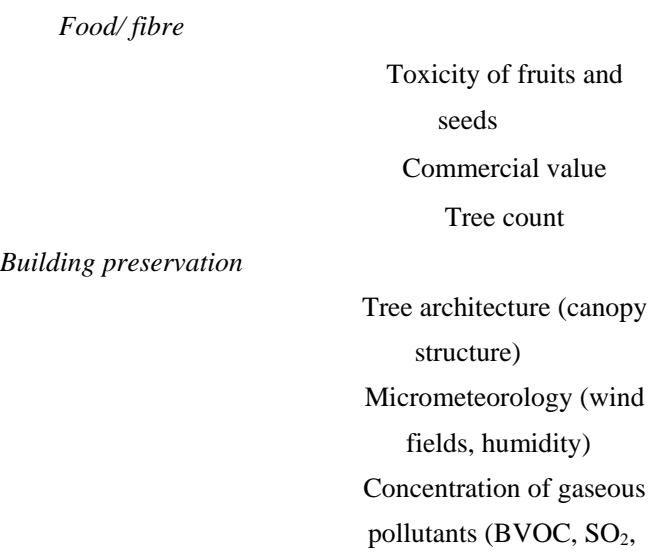

190 Table 3. An overview of the available document types reviewed for different provisioning services scoped in

191 this study. Alongside, the distinct management initiatives on a pan-European scale is provided in the last 192 column.

\begin{tabular}{|c|c|c|c|c|c|c|c|c|c|}
\hline \multirow[b]{2}{*}{ Region $^{1}$} & \multirow[b]{2}{*}{ City } & \multicolumn{4}{|c|}{ Provisioning services } & \multicolumn{2}{|c|}{ Green Infrastructure data } & \multicolumn{2}{|c|}{ Management activities } \\
\hline & & Food & $\begin{array}{c}\text { Raw } \\
\text { materials }\end{array}$ & Freshwater & $\begin{array}{l}\text { Medic } \\
\text { inal } \\
\text { resour } \\
\text { ces }\end{array}$ & $\begin{array}{c}\text { Tree } \\
\text { population } \\
\text { in the city }\end{array}$ & GI area in ha & $\begin{array}{c}\text { Manage } \\
\text { ment } \\
\text { plan }\end{array}$ & Annual plans \\
\hline $\begin{array}{l}\text { Northern } \\
\text { Europe }\end{array}$ & London & $\begin{array}{l}\text { Commun } \\
\text { ity } \\
\text { Websites } \\
\text {, Reports }\end{array}$ & $\begin{array}{c}\text { Forestry } \\
\text { Commissio } \\
\text { n, England } \\
\text { Report }\end{array}$ & $\begin{array}{c}\text { London } \\
\text { Infrastrustur } \\
\text { e Plan 2050; } \\
\text { Green } \\
\text { Infrastructur } \\
\text { e Task Force } \\
\text { Report }\end{array}$ & N/A & $\begin{array}{l}\text { The } \\
\text { Mayor's } \\
\text { Tree and } \\
\text { Woodland } \\
\text { Framework } \\
\text { for London }\end{array}$ & $\begin{array}{c}\text { London Tree } \\
\text { Officers } \\
\text { Association } \\
\text { website. } \\
\text { Reports }\end{array}$ & $\begin{array}{c}\text { Forestry } \\
\text { Commis } \\
\text { sion } \\
\text { England, } \\
\text { Good } \\
\text { urban } \\
\text { forest } \\
\text { practice } \\
\text { in } \\
\text { London }\end{array}$ & $\begin{array}{c}\text { London } \\
\text { Green } \\
\text { Infrastructure } \\
\text { Task Force } \\
\text { Report; } \\
\text { London Tree } \\
\text { Officer: } \\
\text { Association } \\
\text { website }\end{array}$ \\
\hline $\begin{array}{l}\text { Western } \\
\text { Europe }\end{array}$ & $\begin{array}{l}\text { Amster } \\
\text { dam }\end{array}$ & $\begin{array}{l}\text { PhD } \\
\text { thesis; } \\
\text { Reports }\end{array}$ & $\begin{array}{l}\text { GREENS } \\
\text { URGE } \\
\text { Report; } \\
\text { National } \\
\text { Databeses }\end{array}$ & Basin D & N/A & $\begin{array}{c}\text { Tree survey } \\
\text { report; } \\
\text { Website }\end{array}$ & GIS & $\begin{array}{c}\text { Manage } \\
\text { ment } \\
\text { Plans }\end{array}$ & $\begin{array}{c}\text { Structure } \\
\text { Vision }\end{array}$ \\
\hline $\begin{array}{l}\text { Eastern } \\
\text { Europe }\end{array}$ & Sofia & $\begin{array}{l}\text { Commun } \\
\text { ity } \\
\text { reports }\end{array}$ & $\begin{array}{c}\text { National } \\
\text { statistics, } \\
\text { reports, } \\
\text { Forest } \\
\text { managemen } \\
\text { t plant }\end{array}$ & $\begin{array}{c}\text { Basin } \\
\text { Directorates, } \\
\text { Master plans }\end{array}$ & $\begin{array}{l}\text { Maste } \\
\text { r } \\
\text { plans, } \\
\text { report } \\
\text { s }\end{array}$ & $\begin{array}{c}\text { Master } \\
\text { plans, } \\
\text { Green } \\
\text { passport, } \\
\text { reports, } \\
\text { inventory, } \\
\text { national } \\
\text { MAES in } \\
\text { urban areas }\end{array}$ & $\begin{array}{c}\text { GIS, } \\
\text { orthophotos, } \\
\text { Master plan }\end{array}$ & $\begin{array}{c}\text { Green } \\
\text { systems, } \\
\text { Master } \\
\text { plans, } \\
\text { Regulati } \\
\text { on and } \\
\text { legislatio } \\
n\end{array}$ & $\begin{array}{c}\text { Green } \\
\text { systems }\end{array}$ \\
\hline $\begin{array}{l}\text { Southern } \\
\text { Europe }\end{array}$ & $\begin{array}{c}\text { Ljubljia } \\
\text { na }\end{array}$ & $\begin{array}{c}\text { Reports, } \\
\text { Thesis }\end{array}$ & $\begin{array}{c}\text { Statistical } \\
\text { office, } \\
\text { reports, } \\
\text { Forest } \\
\text { managemen }\end{array}$ & $\begin{array}{l}\text { Municipality } \\
\text { management } \\
\text { plans, water } \\
\text { monitoring } \\
\text { reports, }\end{array}$ & $\begin{array}{l}\text { Repor } \\
\text { ts, } \\
\text { Thesis }\end{array}$ & $\begin{array}{c}\text { Statistical } \\
\text { office, } \\
\text { Municipalit } \\
\text { y } \\
\text { managemen }\end{array}$ & $\begin{array}{l}\text { Municipality } \\
\text { management } \\
\text { plans, } \\
\text { Municipality } \\
\text { green }\end{array}$ & $\begin{array}{l}\text { Regional } \\
\text { Master } \\
\text { plans, } \\
\text { Municip } \\
\text { al and }\end{array}$ & $\begin{array}{c}\text { Municipality } \\
\text { management } \\
\text { plans, Forest } \\
\text { management } \\
\text { plans }\end{array}$ \\
\hline
\end{tabular}




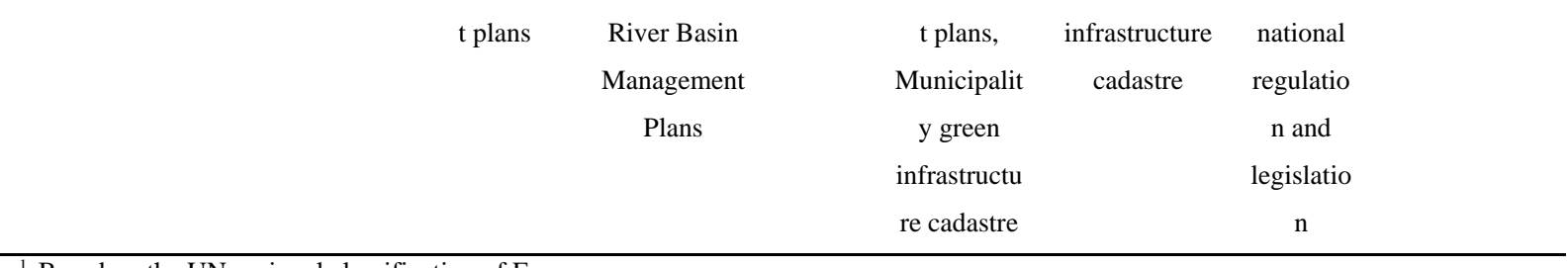

${ }^{1}$ Based on the UN regional classification of Europe

193

194

195

196

197

198

199

200

201

202

203

204

205

\subsection{Four-city evaluation}

The peculiarities emerging from the four-city evaluation are presented in Table 3 . It shows the regional portfolio and transferable learning points, based on regional hotspots of preferred goods and services acquired from the evidence base generated from an extensive European literature survey of the recent trends in goods and services provision potentials from the urban common. We consider this would pave the essential pathway for establishing sustainable policy strategies for the potential role of the commons, specifically in terms of resource provisioning to meet the growing demands, thereby reducing the 'ecological footprint' of future cities (Wackernagel et al., 2006). Progressively, this will facilitate a more integrated, policy framework for enhanced goods and services delivery from existing, as well as future strategic plantations, alongside their prevalent role in local climate regulation and pollution mitigation, which should be incorporated in future dynamic urban planning globally.

Distinct regional peculiarities were noted connecting the city dwellers to the urban common in the four cities located in characteristically distinct European regions. The distribution of wealth and power within societies seems to be strongly influencing the composition of urban ecology (mainly species distribution and structure) as well as the trends in goods and other resource acquisition from the urban commons in these regions. Our observation corroborates with the literature on human-plant interactions (McLain, 2012), emphasizing that humans need to be treated as endogenous factors in dynamic, socially and spatially heterogeneous urban ecosystems. Concerning specifics of the East and South European region, urban population in smaller urban areas and peri-urban territories rely more intensely on the commons for their goods using traditional practice in the past, while population in bigger cities has rapidly departed from these values and moved to global resource exploitation. Both Ljubljana and Sofia bear similarities in goods and services provisioning, presumably attributed to their common socialist backgrounds. On the other hand, the concept of urban commons in the cities started much earlier in London and Amsterdam. While the former two cities exhibit stronger influence of the socio-cultural practices, the latter two have more developed plans and strategies identifying the role of the urban common in promoting goods and services provisioning. The four-city comparison also indicates conflict of interests between NTFP/food gatherers and land managers, as well as between gatherers and other citizens over gathering, particularly in availing the resources from the public spaces. These aspects of urban ecosystem services are still uncomprehendable and need to be addressed towards effective governance of provisioning of goods and services from different components of the urban common in future to make them more practical as means to meet urban demands.

\section{Discussion}

\subsection{Meta-data assessment}


The following geographical trends were observed - North Western Europe: There is more developed framework for utilization of urban commons in the majority of north-western European countries, with marked 230 advancements in green strategies. For example, the UK (Armson et al., 2013; Mell et al., 2013), the Netherlands

231 (Climate Proof Cities: Final Report, 2014; Kleerekoper et al., 2012), Germany (Haase et al., 2012; Larondelle 232 and Haase, 2013; Pauleit and Duhme, 2000) and Finland (Tyrväinen et al., 2003). Mediterranean region:

233 There is more traditional approach to extracting the benefits from street trees, as well as the resources from 234 urban and periurban forests in this region, for example in Portugal (Soares et al., 2011) or Italy (Barbante et al., 235 2014). South East Europe: Urban forestry is still an emerging concept in this region. This makes urban 236 common governance all the more important agenda for effective delivery of green infrastructure in the near-to-long term future (Bentsen et al., 2010). However, there have been strong evidence of traditional practice 238 of reliance on green areas for provision of food, fodder, fuel, wood, and timber for construction, for example in 239 Croatia (Beljan et al., 2015). Recently, these countries are facing with swift changes. Transition from 240 monopolistic and one-party rule to democratic governance, fast growth of the population in the cities, 241 urbanization and industrialization have led to changes in social and cultural lifestyle of the citizens. Following 242 the MAES framework, a methodology for mapping and assessment of urban ecosystems and their services in 243 Bulgaria was developed (Zhiyanski et al., 2017). Therefore, the assessment of urban ecosystems needs to 244 include an indicator that can reveal this heterogeneity in an appropriate manner. The combination of built 245 structures and green spaces determines the flows of energy and matter which are vital for the ecosystem 246 functions. Nedkov et al. (2017) proposed the integrated index of spatial structure, which provides appropriate 247 information for different aspects of urban ecosystems which refer both to their structure and function focusing 248 on type of UGI and was applied in the national assessment of ES in urban ecosystems in Bulgaria. Further 249 studies would support the analysis of the balances "potential-flows", "demand-consumption" and 250 "supply-demand" of ecosystem services and the role of UGI. The results of such an expanded version of the 251 assessment approach are expected to be a highly informative for ES economic valuation (Nedkov et al., 2017).

\subsection{Four-city evaluation}

\subsubsection{Sofia:}

There is greater emphasis on incorporating shared urban green space in regulating and material ecosystem services concept and strategy alongside extraction of NTFPs. In the national legislative documentation of Sofia, the urban common is recognized as an important part of the planning process. This approach is intended to overcome typical issues of fragmented green spaces within the urban area and their disconnect with the peri-urban shared spaces, thereby enabling the city's capacity to meet the needs of the citizens. Sofia's planning authorities look for more studies and explanatory work for improvement of its urban common in terms of management and social services it can provide. One of the main objectives of Sofia's Master Plan is to improve conservation, restoration and development of the elements of its green system and construction of new forest parks within the territory of the city. The ongoing process of broader implementation of ecosystem services concept in local planning in Sofia Municipality is based on experimental study performed by Sofproect company (https://sofproect.com/en/what-we-do/), supported by scientific experts. The completed initiatives of Vision Sofia 2050 and Mapping and assessment of ecosystem services for Sofia district create opportunities for use of more public green spaces, integrating them with other urban systems in order to improve the overall spatial aesthetics and city identity, alongside minimization of fragmentation through creation of links with the 
city periphery. The development of a methodology for mapping and biophysical assessment of ecosystem services and for their economic evaluation aims to facilitate planning and informed management of green and blue infrastructure in Sofia Municipality is supported and the product will be directly implemented for the decision-making process. This in turn will accrue enhanced productivity of green biomass, effective use of different products from green spaces, improved air quality and microclimate, as well as better quality of life and positive effect on the local economy.

4.2.2 Ljubljana: Recent efforts in urban planning process of this city have been focused on mitigating large scale disturbances implicating the state of health of its urban common, such as the ice-storm in 2014, bark beetle outbreak in 2016, etc. After 1991, Ljubljana became a capital of the Republic of Slovenia and the whole region recorded a very dynamic economic development, attracting new immigrations to the region, which accelerated after joining the EU in 2004 (Rebernik, 2014). The urban common has been an important component of urbanization already during the socialism but has recently gained more prominence in the post-socialistic period (Ostojić et al, In print). For example, in 1993 the Forestry department of the Biotechnical Faculty, University of Ljubljana faculty organized a conference in Ljubljana entitled: Urban and peri-urban forests: our common goods (Golob, 1993), highlighting huge interest in active management of goods and services from urban GI at the national level.

In the Environmental Action Programme (EAP) for the period 2007-2013, the city administration defined clear goals and measures towards sustainable growth along with conservation of biodiversity, focusing on the establishment of sustainable mobility system, energy efficiency and the use of renewable energy sources. This has aimed at securing long-term natural drinking water supply and protection of nature and green areas (Loose et al., 2008), including urban common areas. EAP for the period 2014-2020 is focusing on goals and measures, aiming at long-term protection of water sources in the City of Ljubljana, protection of natural environment, urban gardening and local self-sufficiency (Jazbinšek et al., 2014). The conservation of biodiversity and the successful management of protected natural areas in the City of Ljubljana, including the urban commons, is implemented by conservation and improvement of the biodiversity, establishment of a comprehensive system for the effective management of natural features and protected areas and the establishment and effective management of a comprehensive Green System for Ljubljana. The nomination of the City of Ljubljana as the Green Capital of Europe 2016 proved that the city represents an example of good practice in terms of integrating and promoting sustainable development and nature conservation in the municipality (Strojin Božič et al., 2016). This enabled the city authorities to successfully compose the partnership with several cities in an Interreg Danube Transnational project URBforDAN: Management and Utilization of Urban Forests as Natural Heritage in Danube Cities (http://www.interreg-danube.eu/approved-projects/urbfordan). Within the project, the partner cities will benefit from Ljubljana's achievements to date in developing new standards in sustainable management of urban and peri-urban forests and committing to sustainable use of their resources. Under the strategic management plan for the Green System for Ljubljana, all urban and peri-urban green spaces will be developed, importantly contributing to the Master plan of the City of Ljubljana. In addition, an initiative for joint UGI management is being established, introducing a participatory approach by including the stakeholders in decision making and management process. A novel compensation model is being developed for goods and services provisioning from the urban common for the members of the initiative. 
4.2.3 Amsterdam: There is greater emphasis on incorporating urban food strategy alongside extraction of NTFPs from the commons in this city. It has recently been a case study city on the GREEN SURGE study on

311 planning and governance of UGI (http://greensurge.eu). There are a number of green space initiatives, ranging

312 from community parks to city-wide projects, funded mainly through the citizen foundations and other

313 nongovernmental organizations. In 2005, Amsterdam was declared the Elm city of Europe, with over 75,000

314 Elm trees lining the city's streets and canals. It has over 350 hectares of land devoted to urban gardens (van

315 Leeuwen et al., 2010) and adopts an urban food strategy focusing on tree-based resources, developing

316 innovative urban planning agenda, overcoming the conventional urban-rural divide in food policy making

317 (Wiskerke and Viljoen, 2012; Zwart, 2012). It has initiated innovative schemes for cooking in a neighborhood

318 park using local produce. Historically, during the Second World War, the city's common areas provided food

319 and fuel to Amsterdam residents. More recently, greater emphasis has been laid on introducing social

320 innovation and food initiatives in Amsterdam East through reliance of locally harvested food/fruit resources

321 from trees. In 2019 the Municipality of Amsterdam developed a strategy to enable its growing population to

322 better enjoy the benefits provided by nature, while endowing it with a more attractive living environment.

323 Urban green infrastructure is therefore known as a source for material goods and benefits as well as regulation

324 and cultural services to people and society, which can directly and indirectly improve the quality of the living

325 environment. The strategies in the Quality Impulse Green (KwaliteitsImpuls Groen) were translated into four

326 scenarios that describe how the city's green infrastructure will be expanded and improved over the next few

327 years. Recently (2019), the City of Amsterdam has set an ambitious target to be a fully circular economy city by

328 2050, which it envisages to achieve by fostering local and sustainable food production practices (like

329 permaculture) and resilient food system in urban and peri-urban areas, alongside boosting local biodiversity

330 (COLOPHON, 2019).

4.2.4 London: The London districts of Wimbledon, Clapham, Ealing, all have popular urban commons.

333 There is greater awareness and emphasis on communty-scale provisioning of wood fuel, harvesting edible

334 food/fruit, freshwater restoration from these commons; on the other hand, NTFP extraction is relatively small.

335 Recently, the London Infrastructure Plan 2050 established a Green Infrastructure Task Force to identify the

336 infrastructure needs for London over the coming decades (GLA, 2016; DLP, 2019). The plan acknowledged

337 green infrastructure as an essential integral part of the city's vital systems alongside the city's transport, energy,

338 water, waste and digital infrastructure. The Mayor's Tree and Woodland Framework for London has estimated

339 city's tree population to be around 7 million, with over a quarter located in the publicly owned urban woodlands

340 (occupying around $8 \%$ of the city's land area), the remaining located in parks (and open spaces), as well as

341 along roads. It is noteworthy that not all Londoners have access to good parks or live in green neighborhoods. In

342 the recent London Environment Strategy (2018), the Mayor has set target for more than half of London to be

343 green by 2050 (The National Park City, http://www.nationalparkcity.london/). Also, the full economic value

344 that green infrastructure provides to the City is expected to be part of future decision making about the city. The

345 London Environment Strategy (LES, 2018) sets out actions to protect, increase and improve London's green

346 infrastructure through the following initiatices: a) making it the first National Park City, b) expanding and

347 improving London's urban forest; c) highlighting the economic value of London's natural capital following the

348 Natural capital accounts for public green space (NCA, 2017); d) providing guidance and support to help people

349 manage and create habitats for wildlife and enhance London's biodiversity, e g. application of Urban greening 
factor for London (Grant, 2017); e) making maps, data and research available to help others to make a case for

351 and identify priorities for green infrastructure in their local area; f) including policies in the new London Plan

352 (DLP, 2019) to protect the green belt and our best wildlife habitats, and to ensure that new developments

353 include enough urban greening; g) supporting communities and others to improve London's greenspaces (GG,

354 2019) and opportunities to enjoy nature through the Greener City Fund.

355 A number of London woodlands have 'Friends of' groups that get involved in a range of activities

356 including volunteer work. This initiative provides new ways for people to develop a positive relationship with

357 their local woodland. It is important that a diverse range of people get involved in participation processes to aid

358 social inclusion and ensure that a greater understanding of diverse needs is recognized. At present, the majority

359 of these commons provide basic resources to the local community, including, wood fuel, garden mulch; only a

360 small proportion of total output is suitable for higher value products and timber. The Forestry Commission

361 England has produced guidelines for good urban forest practice in London, which among other topics has

362 specific focus on management of woodland for wood fuel (FC, 2016). The UK Renewable Energy Roadmap

363 places bioenergy at the forefront of the Government's plans to meet the Renewable Energy Directive objectives

364 in 2020 (DECC, 2012). According to the London Plan (GLAa, 2015), larger developments are now required to

365 produce $20 \%$ of their energy needs from on-site renewable sources (GLAa, 2015). The London Mayor's Energy

366 Strategy also supports biomass as a renewable fuel in boilers and combined heat and power (CHP) units (GLAb,

367 2015), gauging the potential role of urban commons in provision of locally sourced wood fuel as the most cost-

368 effective practical way of meeting this requirement. Practical applications can range from traditional heating of

369 larger buildings with either wood chip or wood pellets, as well as through increased input to CHP and

370 absorption cooling systems with the advancement of these technologies. Besides, there are community level

371 initiatives on fruit picking and food harvesting from these commons, for example the Urban Harvest initiative

372 (https://urbanharvestuk.org.uk) in North London, which promotes harvest and redistributions of unwanted

373 fruits and other edible food and resources from forest floors from organized foraging events.

\section{5. Conclusions}

376 The study presented a pan-European perspective on enhancing the management of goods and services 377 provisioning from the urban common. Our synoptic evaluation has highlighted some regional peculiarities in 378 provisioning of goods and services from tree-based urban GI across different socio-geographical settings. The 379 pan-European expert elicitation exercise noted active management of the urban common as positively 380 impacting on the performance of the majority of provisioning services, while environmental change impacts 381 were found to be overriding and adversely influencing the provisioning of material resources (mainly NTFPs 382 and woody biomass). Despite the environmental change impacting negatively on provisioning of NTFPs and 383 woody biomass, the 'effective impact' score of practical interventions (planning and/or management) and 384 limitations (governance) still showed an upward trend, largely due to the improved management practices 385 counterbalancing the environmental change impacts.

386 The four-city case study highlighted some peculiarities of regional best practices in management of goods 387 and services, attributed largely to the socio-cultural practices and the policy drivers in each of the 388 macro-geographical regions. Albeit, there is need for greater transferability of best practice across Europe in 389 harmonizing the varied regional intensities in provisioning of goods and services. Due to lack of defined 
indicators about utilization of ecosystem goods and services provided by the urban commons, some trends and conclusions could be outlined only indirectly, analyzing specific local features and management approaches.

392 Based on our literature review, we conclude that there is already a growing awareness among urban planners 393 and practitioners to boost the provisioning services of the urban common in order to develop resilient, sustainable city-dwelling communities. However, our study elucidates that while the concept of urban common is well-embedded in the local spatial development plans across Europe, there are still some shortcomings pertaining to the intensities of goods and service acquisitions in different regions.

The concept of human-plant interaction, specifically the scope of harmonizing the urban-centric societal needs with the goods and services provided by the urban common, is an area that cannot be overlooked by planners and policy makers. As a next step, we recommend specific performance indicators for provisioning of goods and services from the urban common to be incorporated in a regulatory framework for regular monitoring on an annual basis. Further, the idea of the four-city case study can be considered as a template for repeating similar cross-city analysis and can be used even on global levels. This can serve as starting point for further analysis as (good, bad, interesting) example and can be used as data source for other comparisons.

Acknowledgments: The pan-European consortium providing inputs to this manuscript was supported by EU-FP7 grant FP1204, under the initiative of the European Cooperation in Science and Technology (COST1204-Action GreenInUrbs).

\section{References}

Armson D, Stringer P, Ennos A (2013) The effect of street trees and amenity grass on urban surface water runoff in Manchester, UK. Urban Forestry \& Urban Greening, 12: 282-286.

Armstrong H, Lope, A (2016) Re-ruralising the urban edge: lessons from Europe, USA \& the global south. In Balanced Urban Development: Options and Strategies for Liveable Cities. Springer, Cham, 17-27.

Arnberger A, Eder R (2006) Monitoring recreational activities in urban forests using long-term video observation. Forestry, 80: 1-15..

Barbante E, Calvo E. Sanesi G, Selleri B, Verlič A, Vilhar U (2015) Urban and periurban forests: management, monitoring and ecosystem services. Emonfur Life +project experiences, pp. 279.

Beljan K, Posavec S, Jerčić K (2015) Economic valuation of urban trees: Ribnjak Park case study, Zagreb. South-east European forestry, 6: 119-127.

Bentsen P, Lindholst A, Konijnendijk CC (2010) Reviewing eight years of Urban Forestry \& Urban Greening: Taking stock, looking ahead. Urban Forestry \& Urban Greening, 9: 273-280.

Bolea V, Chira F, Chira D, Mantale C. (2015) West-slope forest of Usturoi Valley, part of Baia Mare Central Park. Revista de Silvicultură și Cinegetică, 20: 15-24.

Bowler DE, Buyung-Ali L, Knight TM., Pullin AS. (2010) Urban greening to cool towns and cities: A systematic review of the empirical evidence. Landscape and urban planning, 97: 147-155.

Buizer M, Elands B， Vierikko K (2016) Governing cities reflexively—The biocultural diversity concept as an alternative to ecosystem services. Environmental Science \& Policy, 62:7-13. study in Belgrade). Journal of Geochemical Exploration, 188:308-317. 
Capotorti, G., Mollo, B., Zavattero, L., Anzellotti, I., \& Celesti-Grapow, L. (2015). Setting priorities for urban forest planning. A comprehensive response to ecological and social needs for the metropolitan area of Rome (Italy). Sustainability, 7(4), 3958-3976.

Carlini M, Castellucci S, Cocchi S, Manzo A (2013) Waste Wood Biomass Arising from Pruning of Urban Green in Viterbo Town: Energy Characterization and Potential Uses, International Conference on Computational Science and Its Applications Springer, Berlin, Heidelberg: 242-255.

Casado-Arzuaga I, Madariaga I., Onaindia M (2013) Perception, demand and user contribution to ecosystem services in the Bilbao Metropolitan Greenbelt. Journal of environmental management, 129: 33-43.

Chisăliță I, Vasile D, Dincă L (2017) Unele specii de plante culese din parcul Bazoș, județul Timiș, existente în colecția Herbarului Alexandru Beldie de la INCDS București. Revista de Silvicultură şi Cinegetică, 40 : 71-76.

Chrzan A (2015) Necrotic bark of common pine (Pinus sylvestris L.) as a bioindicator of environmental quality. Environmental Science and Pollution Research, 22: 1066-1071.

CICES, 2014. The Common International Classification of Ecosystem Services (CICES) http://cices.eu/. (accessed 21 March 2015)

Climate Proof Cities: Final Report, 2014. KfC Report No:129/2014, pp.128.

COLOPHON Building blocks for the new strategy Amsterdam Circular 2020-2025 Publication date:

Amsterdam, 19 June 2019

https://www.circle-economy.com/wp-content/uploads/2019/06/Building-blocks-Amsterdam-Circular-20

Cvejić R, Eler K, Pintar M, et al (2015) A typology of urban green spaces, eco-system provisioning services and demands. GREENSURGE Project Report, 10:66.

DECC. UK (2012) Bioenergy Strategy. UK Department of Energy and Climate Change, April 2012.

Dimitrov S, Georgiev G, Georgieva M et al (2018) Integrated assessment of urban green infrastructure condition in Karlovo urban area by in-situ observations and remote sensing. One Ecosystem, 3: e21610. doi: 10.3897/oneeco.3.e21610.

Dincă LC, Dincă M, Vasile D, Sparchez G, Holonec L(2015) Calculating organic carbon stock from forest soils, Notulae Botanicae Horti Agrobotanici Cluj-Napoca 43: 568-575.

Djomo SN, Zenone T, De Groote T et al (2015) Energy performances of intensive and extensive short rotation cropping systems for woody biomass production in the EU. Renew. Sust. Energ. Rev. 41: 845-854.

DLP (2019) Draft London Plan - consolidated changes version - July 2019 Greater London Authority, London: 455.

Ebenhard T, Forsberg M, Lind T, et al (2017) Environmental effects of brushwood harvesting for bioenergy. Forest Ecol. Manag. 383: 85-98.

EC. Towards an EU research and innovation policy agenda for nature-based solutions \& re-naturing cities (2015) European Commission, Brussels, pp.70.

Enescu CM, Dincă L, Vasile D (2017) Importance of non-wood forest products for Maramureș County. Revista de Silvicultură şi Cinegetică 40: 92-97. 
FC, Producing fuel from London's trees and woodland. Forestry Commission, England. url:http://www.forestry.gov.uk/pdf/100000FCGuidanceWoodfuelinLondon.pdf/\$FILE/100000FCGuidan ceWoodfuelinLondon.pdf (accessed 8 April 2016)

Ferrara C, Moretti V, Serra P, Salvati L (2015) Towards a sustainable agro-forest landscape assessing land degradation (1950-2010) and soil quality in Castelporziano forest and peri-urban Rome, Italy. Rendiconti Lincei 26: 597-604.

Ferrari B, Corona P, Mancini LD, Salvati R, Barbati A (2017) Taking the pulse of forest plantations success in peri-urban environments through continuous inventory. New Forests, 48: 527-545.

GG (2019) GREY TO GREEN. A guide to community-led depaving projects. Greater London Authority, London: 16.

Giannico V, Lafortezza R, John R, Sanesi G, Pesola L, Chen J (2016) Estimating Stand Volume and Above-Ground Biomass of Urban Forests Using LiDAR. Remote Sens. 8: 339.

GLA (2016) Green Infrastructure Task Force report. Greater London Authority, London,

GLAa. (2015) The London Plan Chapter Five: London's Response To Climate Change. Greater London Authority, March, 2015.

GLAb. (2015) Greater London Authority guidance on preparing energy assessments. Greater London Authority. April 2015.

Godefroid S, Koedam N (2003) Distribution pattern of the flora in a peri-urban forest: an effect of the city-forest ecotone. Landscape and Urban Planning, 65: 169-185.

Golob S (1993) Mestni in primestni gozd - naša skupna dobrina. Zbornik republiškega posvetovanja v okviru tedna gozdov, Zveza društev inženirjev in tehnikov gozdarstva in lesarstva Slovenije. Inštitut za gozdno in lesno gospodarstvo, Ljubljana: 183.

Grant G (2017) Urban Greening Factor for London. Research Report. Greater London Authority, The Ecology Consultancy, London: 33.

Grêt-Regamey A, Brunner SH, Altwegg J, Bebi P (2013) Facing uncertainty in ecosystem services-based resource management. J. Environ. Manag. 127:145-154.

Grunewald K, Syrbe RU, Walz U, et al (2017) Germany's Ecosystem Services - State of the Indicator Development for a Nationwide Assessment and Monitoring. One Ecosystem 2: e14021. Part of: Mapping and assessment of ecosystem condition and ecosystem services across different scales and domains in Europe. doi: 10.3897/oneeco.2.e14021.

Haase D, Schwarz N, Strohbach M, Kroll F, Seppelt R (2012) Synergies, trade-offs, and losses of ecosystem services in urban regions: an integrated multiscale framework applied to the Leipzig-Halle Region, Germany. Ecol. Soc. 17: 22.

Hansen-Møller J, Oustrup L(2004) Emotional, physical/functional and symbolic aspects of an urban forest in Denmark to nearby residents. Scandinavian Journal of Forest Research 19: 56-64.

Hernea C, Tenche-Constantinescu, AM (2013) Variability of Groundwater Quality Parameters from Periurban Area of Timisoara (Romania). Journal of Environmental Protection and Ecology 14: 64-70. Department for Environmental Protection, Ljubljana, Slovenia, pp. 70.

Kachova V, Dincă L (2015) Establishment of agroforestry systems along river basins-functions and features. Revista de Silvicultură și Cinegetică, 20: 64-68. 
Kleerekoper L, van Esch M, Salcedo TB (2012) How to make a city climate-proof, addressing the urban heat island effect. Resour. Conserv. Recy. 64:30-38.

Kohsaka R, Shih W, Saito O, Sadohara S (2008) Urbanization, biodiversity and ecosystem services: challenges and opportunities: a global assessment, Springer Netherlands, pp. 746.

Konijnendijk C (2008) The Forest and the City: The Cultural Landscape of Urban Woodland. New York, NY: Springer, pp. 245.

Konijnendijk C, Thorsen B, Tyrvainen L. et al (2007) Decision-support for land-use planning through valuation of urban forest benefits. Allgemeine Forst Und Jagdzeitung 178: 74.

Larondelle N, Haase D (2013) Urban ecosystem services assessment along a rural-urban gradient: A cross-analysis of European cities. Ecological Indicators 29: 179-190.

LES (2018) The London Environment Strategy. Greater London Authority, London: 442 p.

Liu S, Crossman ND, Nolan M, Ghirmay H (2013) Bringing ecosystem services into integrated water resources management. J. Environ. Manag., 129:92-102.

Livesley SJ, McPherson EG, Calfapietra C (2016) The urban forest and ecosystem services: Impacts on urban water, heat, and pollution cycles at the tree, street, and city scale. Journal of environmental quality, 41:119-124.

Loose A, Jankovič M, Jazbinšek Seršen N (2008) Environmental Action Programme 2007-2013. City of Ljubljana, The Department for Environmental Protection, Ljubljana, Slovenia, 2008, pp. 54

Maes J, Teller A, Erhard M, et al (2013) Mapping and Assessment of Ecosystems and their Services. An analytical framework for ecosystem assessments under action, European Commission, 5:1-58.

Maes J, Zulian G, Thijssen M. et al (2016) Mapping and Assessment of Ecosystems and their Services: Urban ecosystems. $4^{\text {th }}$ Report. European Union, Luxembourg, May 2016, pp.91.

Markkola AM, Tarvainen O, Ahonen-Jonnarth, U, Strömmer R (2002) Urban polluted forest soils induce elevated root peroxidase activity in Scots pine (Pinus sylvestris L.) seedlings. Environmental Pollution 116: 273-278.

McLain RJ (2005) Gathering the city: an annotated bibliography and review of the literature about human-plant interactions in urban ecosystems. Gen. Tech. Rep. PNW-GTR-849. Portland, OR: U.S. Department of Agriculture, Forest Service, Pacific Northwest Research Station, pp. 107.

MEA. (2005) Synthesis report, Millennium Ecosystem Assessment Synthesis Report. Island, Washington, DC., pp.155.

Mell IC, Henneberry J, Hehl-Lange S.; Keskin B (2013) Promoting urban greening: Valuing the development of green infrastructure investments in the urban core of Manchester, UK. Urban For. \&Urban Gree. 12:296-306.

Mundoli S, Manjunath B, Nagendra H (2015) Effects of Urbanisation on the use of Lakes as Commons in the Peri-Urban Interface of Bengaluru, India. Int. J. Urban Sust. Dev. 7: 89-108.

NCA (2017) Natural capital accounts for public green space in London. Greater London Authority, National Trust, Heritage Lottery Fund, London: 35 p.

NCC (2015) UK Natural Capital Committee. Clark, K.H.; Nicholas, K.A. Introducing urban food forestry: a multifunctional approach to increase food security and provide ecosystem services. Landscape Ecol. 28:1649-1669.

Nedkov S, Zhiyanski M, Dimitrov S et al (2017) One ecosystem, Pensoft Publisher (in print). 
Orłowski G, Kasprzykowski Z, Dobicki W et al (2014) Residues of chromium, nickel, cadmium and lead in Rook Corvus frugilegus eggshells from urban and rural areas of Poland. Sci. Total Environ. 490: 1057-1064.

Ostoić S K, Vuletić D, Planinšek Š, Vilhar U, Japelj A (2019) Three decades of urban forest and green space research and practice in Croatia and Slovenia. Forests 10: (In print)

Pauleit S, Duhme F (2000) Assessing the environmental performance of land cover types for urban planning. Landscape Urban Plan. $52: 1-20$.

Paulin M, Remme R, de Nijs T (2019) Amsterdam's Green Infrastructure Valuing Nature's Contributions to People RIVM Letter Report 2019-0021 https://www.rivm.nl/bibliotheek/rapporten/2019-0021.pdf

Perini K, Ottele M, Haas E, Raiteri R (2011) Greening the Building Envelope, Façade Greening and Living Wall Systems. Open J. Ecol. 1: 1-8.

Pesola L, Cheng X, Sanesi G, et al (2017) Linking above-ground biomass and biodiversity to stand development in urban forest areas: A case study in Northern Italy. Landscape and Urban Planning 157: 90-97.

Poe MR, McLain RJ, Emery M, Hurley PT (2013) Urban forest justice and the rights to wild foods, medicines, and materials in the city. Hum. Ecol. 41: 409-422.

Pullin AS, Stewart GB (2006) Guidelines for systematic review in conservation and environmental management. Conserv. Biol. 20: 1647-1656.

Raji B, Tenpierik J, Dobbelsteen A (2015) The Impact of Greening Systems on Building Energy Performance: A Literature Review. Renew. Sustain. Energ. Rev., 45:610-623.

Rebernik D (2014) Population change and urbanisation processes in Ljubljana urban region after 2002. Acta Geographica Croatica 39: 45-63.

Sanesi G, Gallis C, Kasperidus HD (2011) Urban forests and their ecosystem services in relation to human health. Forests, trees and human health, Springer, Dordrecht. 23-40..

Schauppenlehner-Kloyber E, Penker M (2016) Between Participation and Collective Action-From Occasional Liaisons towards Long-Term Co-Management for Urban Resilience. Sustainability 8: 664.

Seidel D, Busch G, Krause B, Bade C, Fessel C, Kleinn C (2015) Quantification of Biomass Production Potentials from Trees Outside Forests-A Case Study from Central Germany. Bioenerg. Res. 1-8.

Shackleton CM, Hurley PT, Dahlberg AC, et al (2017) A Ubiquitous Human Practice Overlooked by Urban Planners, Policy, and Research. Sustainability, 9: 1884.

Soares AL, Rego FC Mcpherson EG, Simpson JR, Peper PJ, Xiao Q (2011) Benefits and costs of street trees in Lisbon, Portugal. Urban For. Urban Gree., 10: 69-78.

Šraj M, Lah A, Brilly M (2008) Measurements and analysis of intercepted precipitation of Silver Birch (Betulapendula Roth.) and Scots Pine (Pinus sylvestris L.) in urban area. Gozdraski vestnik , 66: 406-416.

Strojin Božič Z, Regina H, Maslo G, et al (2015) Environment in the City of Ljubljana: European green capital 2016. City of Ljubljana, The Department for Environmental Protection, Ljubljana, Slovenia, pp. 44.

Tarvainen O, Strömmer R, Markkola A (2011) Urban forest regeneration: Responses of Scots pine seedlings to partial humus removal in mid-boreal N-enriched forests. Landscape Urban Plan. 102: 209-214.

The Orchard Project (2016) Developing resilient communities with the skills to plant, care for and harvest fruit trees; helping us all to rediscover the pleasure of eating home-grown fruit. The Orchard Project, London. www.theorchardproject.org.uk/ (accessed 20 Aug 2016) 
Tiwary A, Kumar P (2014) Impact evaluation of green-grey infrastructure interaction on built-space integrity: An emerging perspective to urban ecosystem service. Sci. Total Environ. 487: 350-360.

Tiwary A, Williams ID, Heidrich O, et al (2016) Development of multi-functional streetscape green infrastructure using a performance index approach. Environ. Pollut. 208: 209-220.

Tyrväinen L (2001) Economic valuation of urban forest benefits in Finland. Journal of Environmental Management 62: 75-92.

Tyrväinen L, Silvennoinen H, Kolehmainen O (2003) Ecological and aesthetic values in urban forest management. Urban For. Urban Gree. 1: 135-149.

602 Țenche-Constantinescu AM, Chira D, Madoșa E et al (2015) Tilia sp. - Urban Trees for Future. Notulae Botanicae Horti Agrobotanici Cluj-Napoca , 43: 259-264.

UN (2013) Composition of macro geographical (continental) regions, geographical sub-regions, and selected economic and other groupings. United Nations Statistics Division url: http://unstats.un.org/unsd/methods/m49/m49regin.htm\#europe (accessed 15 Sept 2015).

van Leeuwen E, Nijkamp P, Vaz TD (2010) The multifunctional use of urban green space. Int. J. Agric. Sustain. 8: $20-25$.

Vilhar U, Simončič (2012) Identification of Key Indicators for Drinking Water Protection Services in the Urban Forests of Ljubljana. SEEFOR South-east European Forestry 3: 103-113.

611 Wackernagel M, Kitzes J, Moran D, Goldfinger S, Thomas M (2006) The ecological footprint of cities and regions: comparing resource availability with resource demand. Environ. Urban. 18:103-112.

WHO (2016) Global Health Observatory (GHO) data: Urban population growth. The World Health Organisation, Geneva,

615 Wiskerke J, Viljoen A (2012) Sustainable urban food provisioning: challenges for scientists, policymakers, planners and designers. Sustainable Food Planning: Evolving Theories and Practices, Wageningen academic publishers

Zhiyanski M, Doncheva S, Nedkov S et al (2017) Methodology for assessment and Mapping of Urban ecosystems their state, and the services that they provide in Bulgaria. (in print).

Zwart T (2012) Building sustainable food systems: Urban food strategies in Amsterdam and Utrecht. Thesis.

622 https://www.gov.uk/government/groups/natural-capital-committee. (accessed 14 Oct 2015).

623 http://greensurge.eu (accessed on 28.04. 2016).

624 https://urbanharvestuk.org.uk/ (accessed on 28.04. 2016). 